\title{
Spatial Associations of Vines Infected With Grapevine Red Blotch Virus in Oregon Vineyards
}

\author{
Daniel T. Dalton, ${ }^{1, \dagger}$ Richard J. Hilton, ${ }^{2}$ Clive Kaiser, ${ }^{3}$ Kent M. Daane, ${ }^{4}$ Mysore R. Sudarshana, ${ }^{5}$ Julia Vo, ${ }^{5}$ Frank G. Zalom, ${ }^{6}$ \\ Jessica Z. Buser, ${ }^{1}$ and Vaughn M. Walton ${ }^{1}$ \\ ${ }^{1}$ Department of Horticulture, Oregon State University, Corvallis, OR 97331 \\ ${ }^{2}$ Southern Oregon Research and Extension Center, Oregon State University, Central Point, OR 97502 \\ ${ }^{3}$ Oregon State University Extension Service, Umatilla County, Milton-Freewater, OR 97862 \\ ${ }^{4}$ Department of Environmental Science, Policy, and Management, University of California, Berkeley, CA 94720 \\ ${ }^{5}$ Department of Plant Pathology, U.S. Department of Agriculture Agricultural Research Service, University of California, Davis, \\ CA 95616 \\ ${ }^{6}$ Department of Entomology and Nematology, University of California, Davis, CA 95616
}

\begin{abstract}
Spread and in-field spatial patterns of vines infected with grapevine red blotch virus (GRBV) were documented in Oregon vineyards using field sampling, molecular diagnostics, and spatial analysis. Grapevine petiole tissue collected from 2013 to 2016 was tested using quantitative polymerase chain reaction for GRBV. At Jacksonville in southern Oregon, $3.1 \%$ of vines were infected with GRBV in 2014, and GRBV incidence reached $58.5 \%$ of study vines by 2016. GRBV-infected plants and GRBVuninfected plants were spatially aggregated at this site in 2015 , and infected plants were spatially associated between years 2015 and 2016. In a southern Oregon vineyard near Talent, $10.4 \%$ of vines were infected with GRBV

in 2014, and infection increased annually to $21.5 \%$ in 2016. At Talent, distribution of the infected vines was spatially associated across all years. GRBV infection was highest at Yamhill, in the Willamette Valley, where $31.7 \%$ of the tested vines had GRBV infection in 2014. By 2016, 59.2\% of the vines tested positive for GRBV. Areas of aggregation increased and were spatially associated across all years. From 2013 to 2015, GRBV was not detected at Milton-Freewater in eastern Oregon. Spatial patterns of GRBV infection support evidence of spread by a mobile insect vector. GRBV is a significant threat to Oregon wine grape production because of its drastic year-over-year spread in affected vineyards.
\end{abstract}

The epidemiology of grapevine viruses is a subject of particular interest to the grape industry because of perceived negative effects of viruses on fruit yield and wine quality. To date, more than 80 viruses or virus-like agents are known to infect commercial cultivars of grapevine (Vitis spp.) (Maliogka et al. 2015; Martelli 2014). Grapevine leafroll-associated viruses (GLRaVs) (Closteroviridae: Ampelovirus, Closterovirus, and Velarivirus) are among the grapevine viruses of primary economic concern worldwide (Almeida et al. 2013; Maliogka et al. 2015; Naidu et al. 2015). Infection by GLRaVs leads to symptoms of grapevine leafroll disease (GLD): interveinal reddening or chlorosis, cupping of the leaf blade, uneven ripening of grape clusters, reduced crop quality, and declining plant vigor (Almeida et al. 2013; Naidu et al. 2015).

Some Oregon vineyards showing apparent symptoms of GLD tested negative for strains of GLRaV. In 2012, a virus damaging to grapevine was revealed, and its presence helped explain apparently GLD-symptomatic vines that tested negative for GLRaVs. This new-to-science virus is in the family Geminiviridae and was initially named Grapevine Cabernet franc-associated virus (Krenz et al. 2012), Grapevine red blotch-associated virus (Al Rwahnih et al.

${ }^{\dagger}$ Corresponding author: D. T. Dalton; daniel.dalton@ oregonstate.edu

Funding: Financial and in-kind assistance was provided by the collaborating growers, Oregon Wine Board, Oregon Wine Research Institute, California Department of Food and Agriculture Pierce's Disease Control Program, U.S. Department of Agriculture Agricultural Research Service (USDA-SCRINIFA grant 2009-51181-06027 and NP303 National Program), University of California, Berkeley, and University of California, Davis.

The author(s) declare no conflict of interest.

Accepted for publication 29 December 2018.

This article is in the public domain and not copyrightable. It may be freely reprinted with customary crediting of the source. The American Phytopathological Society, 2019.
2013), Grapevine red leaf-associated virus (Poojari et al. 2013), and Grapevine geminivirus (Seguin et al. 2014), but it is now universally described as Grapevine red blotch virus (GRBV) (Varsani et al. 2017). GRBV is the causal agent of red blotch disease (RBD) and is the type species of the genus Grablovirus (Varsani et al. 2017; Yepes et al. 2018). Additional proposed species of Grablovirus, tentatively named Wild Vitis virus 1 and Prunus geminivirus A, have been further identified (Al Rwahnih et al. 2018; Perry et al. 2018). Isolates of these newly described geminivirus species have circular monopartite ssDNA genomes that are slightly larger than those of most other Geminiviridae at $3.2 \mathrm{~kb}$ (Al Rwahnih et al. 2013; Varsani et al. 2017). $\mathrm{RBD}$ can compromise the ripening process of grapes postvéraison (Blanco-Ulate et al. 2017), and symptoms expressed in leaf tissue can be similar to those of GLD (Sudarshana et al. 2015).

Spread of GRBV was documented from 2014 to 2016 at a vineyard in Napa Valley, California (Cieniewicz et al. 2017). Insects collected from that site and representing at least three families within the order Hemiptera tested positive for the presence of the virus, indicating successful virion uptake by diverse insect taxa (Cieniewicz et al. 2018). The threecornered alfalfa hopper, Spissistilus festinus Say (Hemiptera: Membracidae), was found to transmit GRBV under greenhouse conditions (Bahder et al. 2016), making GRBV only the second known geminivirus to be transmitted by a member of Membracidae, following the discovery that the treehopper Micrutalis malleifera (Fowler) transmits tomato pseudo-curly top virus (TPCTV) in tomatoes (Simons and Coe 1958). The field distribution of $S$. festinus was spatially associated with GRBV-infected grapevines in a vineyard block in California where GRBV was spreading (Cieniewicz et al. 2018). Treehopper species including S. festinus and numerous species belonging to the genus Tortistilus occur as incidental species across the United States, including in wine grape production regions of Oregon and California (Kopp and Yonke 1979). Host plants for these insects are common in the vegetative communities surrounding vineyards in western North America (Goeden and Ricken 1986; Swiecki and Bernhardt 2006; Valenti et al. 1997). Despite the presence of the vector S. festinus and closely 
related species in Oregon, no study has thus far reported the patterns of GRBV distribution in Oregon vineyards. The objectives of this study were to document the infection patterns and spread of GRBV in Oregon vineyards.

\section{Materials and Methods}

Site selection and description. Vineyards were initially selected based on grower concerns about the presence or apparent spread of grapevine viruses. Previously, vineyard blocks were surveyed for infestations of Pseudococcus maritimus (Ehrhorn) (Walton et al. 2013) and the presence of GLD-like symptoms postvéraison. Vines representing the vineyard study blocks were assessed using real-time quantitative polymerase chain reaction (qPCR) from 2013 to 2016 for infection by GRBV. Study blocks were located in three Oregon wine grape regions (Jones et al. 2003) and are hereafter identified by proximity to the nearest town: in eastern Oregon, MiltonFreewater was planted in 2003 and was surveyed for GRBV from 2013 to 2015; in southern Oregon, a vineyard near Jacksonville was established in 2010, and a vineyard near Talent was planted in 1990. The southern Oregon sites were surveyed for GRBV from 2014 to 2016. In the Willamette Valley, the Yamhill site was planted in 1990 and surveyed for GRBV from 2013 to 2016.

The Milton-Freewater block was in a heavily managed area formerly occupied by an apple orchard with no surrounding wild habitat. The Jacksonville site was previously a pear orchard block with riparian vegetation dominated by Oregon white oak (Quercus garryana) to the north and east. Seedling grapevines were found at Jacksonville along the riparian habitat and nearby fence lines. Testing in 2015 indicated that GRBV was present in grapevine seedlings in the habitat immediately surrounding the vineyard block (data not shown). The area to the south and west was planted to wine grapes. The Talent block was bordered by a diversified organic vegetable and berry farm to the north and wine grapes to the east, south, and west. The Yamhill block was bordered to the north and east by a stand of Oregon white oak, to the east and west by wine grapes, and to the south by unmanaged riparian habitat dominated by ash (Fraxinus spp.), blackberry (Rubus armeniacus), hazelnut (Corylus spp.), and Oregon white oak.

The sampling schemes differed at all sites based on the layout of study blocks. The Milton-Freewater study block was composed of the cultivars Petit Verdot, Malbec, Merlot, and Cabernet franc. In 2013, leaves from every eighth vine within each of 20 consecutive rows were collected, providing material for GRBV laboratory tests of approximately 10 vines in each row. In 2014, leaves from vines alternating with those selected in 2013 were collected from within the same rows. Leaves from vines previously tested in 2013 and 2014 were collected in 2015 for qPCR analysis of the presence of GRBV. At Jacksonville, approximately 20 vines of cultivar Pinot noir were examined in each of 10 even-numbered rows in 2014 and 2015. Vines were spaced $1.8 \mathrm{~m}$ apart within rows. Vines in even-numbered rows were examined, producing observations in rows that were spaced $5.5 \mathrm{~m}$ apart. The eastern-most row bordering the field edge of the Jacksonville block was row 14, and the block extended to the west past row 32 . Leaves from every fourth vine were collected in 2014, and collections in 2015 were taken from the same vines. Because of the grower's aggressive removal of virussymptomatic vines, sampling at Jacksonville in 2016 was restricted to a subset of vines that were tested in 2014 to 2015 . At Talent, approximately 10 vines were sampled in 20 consecutive rows, beginning at row 19, of a block containing cultivars Cabernet franc and Pinot gris. Leaves were collected from every fifth vine each season from 2014 to 2016. In this block, rows were spaced $3 \mathrm{~m}$ apart, with in-row spacing of $1.8 \mathrm{~m}$ between individual vines. At Yamhill, surveyed rows of Pinot noir were coupled with $1 \mathrm{~m}$ between coupled rows and $1.6 \mathrm{~m}$ between noncoupled rows. Plants were spaced $1 \mathrm{~m}$ apart within rows 44 to 63 . In 2013, leaves from every seventh vine beginning from the 28th vine from the northern edge of a row were assayed with qPCR in 20 rows to assess approximately 10 vines per row for the presence of GRBV. In 2014, leaves were collected from every seventh vine beginning from the 31 st vine from the northern edge of a row to combine with the previous season's collections to assay a total number of approximately 20 individual vines per row. In 2015, leaves from previously assayed vines were collected for analysis. In 2016, fresh tissues from previously virus-negative vines were assayed for the presence of GRBV.

Leaf tissue samples. Leaf petiole tissue was collected in all sites using the described predetermined grid pattern of each block. At each site and collection date (Table 1), two to five leaves were collected from basal and middle areas of the current season's growth by inverting a zippered plastic bag and pulling the leaves from the vine without touching the material to the collector's hand. Leaf petioles from sampled regions of GRBV-infected vines have sufficient titer during the late season to reliably capture GRBV particles for diagnostic assays (Setiono et al. 2018). Tissues were stored in cooled insulated containers during transport to the laboratory and were processed fresh for nucleic acid extraction or stored at $-80^{\circ} \mathrm{C}$ until they could be processed. Positive controls consisted of diluted GRBV DNA or leaf petiole materials that were deep-frozen at $-80^{\circ} \mathrm{C}$ and had previously tested positive for GRBV, and negative controls consisted of leaf petiole materials that had previously tested negative for GRBV. Materials from control vines were handled in an identical manner as the field-collected materials, and buffer controls were added to all runs of the thermocycler. Cross-sections $(1 \mathrm{~mm})$ of fresh or frozen grape petioles were removed using sterilized tools. Approximately $0.2 \mathrm{~g}$ per sample of homogenized petiole tissue was used. In 2013, samples were homogenized using a Precellys 24 Tissue Homogenizer (Bertin Instruments, Montigny-le-Bretonneux, France) at 6,500 Hz for two 10-s cycles with a 30-s intermission between cycles. From 2014 to 2016, samples were homogenized using a Qiagen TissueLyser II (Qiagen, Hilden, Germany). Petiole material was

Table 1. Summary of vineyard leaf petiole samples used in the current study

\begin{tabular}{|c|c|c|c|c|c|c|}
\hline Region & Site & Petiole collection date & $N^{\mathbf{a}}$ & GRBV positive & GRBV negative & $\%$ infected \\
\hline \multirow[t]{3}{*}{ Eastern Oregon } & Milton-Freewater & 15 October 2013 & 199 & 0 & 199 & 0.0 \\
\hline & & 22 September 2014 & 196 & 0 & 196 & 0.0 \\
\hline & & 25 September 2015 & 395 & 0 & 395 & 0.0 \\
\hline \multirow[t]{3}{*}{ Southern Oregon } & Jacksonville & 22 September 2014 & 194 & 6 & 188 & 3.1 \\
\hline & & 17 September 2015 & 195 & 61 & 134 & 31.3 \\
\hline & & 24 August 2016 & 72 & 55 & 17 & 76.4 \\
\hline \multirow[t]{3}{*}{ Southern Oregon } & Talent & 22 September 2014 & 193 & 20 & 173 & 10.4 \\
\hline & & 17 September 2015 & 200 & 34 & 166 & 17.0 \\
\hline & & 12 September 2016 & 196 & 40 & 156 & 20.4 \\
\hline \multirow{4}{*}{ Willamette Valley } & Yamhill & 10 October 2013 & 190 & 61 & 129 & 32.1 \\
\hline & & 13 October 2014 & 173 & 54 & 119 & 31.2 \\
\hline & & 8 October 2015 & 375 & 172 & 203 & 45.9 \\
\hline & & 28 September 2016 & 176 & 37 & 139 & 21.0 \\
\hline
\end{tabular}

\footnotetext{
${ }^{\text {a }} N$ indicates the number of vines sampled each season from 2013 to 2016 and assayed for the presence of grapevine red blotch virus (GRBV) using quantitative
} polymerase chain reaction. 
subsequently incubated in a guanidine thiocyanate buffer ( $\mathrm{pH} 5.0)$ to extract total plant DNA. Sample DNA was further processed using a MagMAX (2014 to 2016) or KingFisher Flex Purification System (2016) (Thermo Scientific, Waltham, MA) using the unmodified MagMAX protocol Am 1836_DW_50_V2 to generate purified nucleic acid extracts for use in qPCR reactions (Osman et al. 2012).

qPCR assays for GRBV. An Applied Biosystems qPCR machine with 7500 Fast System SDS software was used to test all 389 samples for the presence of GRBV in 2013, for 79 samples in 2016 (17.8\% of the season total), and to retest material from 2015 from 19 vines (1.6\% of the season total) at the end of the study period. A QuantStudio 6 Flex Real-Time PCR machine (Thermo Scientific) was used to test all other samples for presence of GRBV. For the latter thermocycler, each $20-\mu$ l reaction was prepared to contain $10.0 \mu \mathrm{l}$ of $2 \times$ SsoFast EvaGreen Master Mix (Bio-Rad Laboratories Inc., Hercules, CA), $2 \mu$ l of polyvinylpyrrolidine, molecular weight 40.000 (PVP$40,10 \% \mathrm{w} / \mathrm{v}), 0.3 \mu \mathrm{l}$ of 1:500 concentration USB ROX passive reference dye (product number 75768, Affymetrix, Inc., Santa Clara, CA), $0.3 \mu \mathrm{l}$ of $10 \mu \mathrm{M}$ primer GVGF1 and $0.3 \mu \mathrm{l}$ of $10 \mu \mathrm{M}$ primer GVGR1 (Al Rwahnih et al. 2013), $1.0 \mu l$ of DNA extract, and $6.1 \mu \mathrm{l}$ of Millipore water. Analysis using the 7500 Fast System SDS in 2016 was performed on $20-\mu 1$ samples containing $10.0 \mu \mathrm{l}$ of $2 \times$ Fast SYBR Green Master Mix (Thermo Scientific), $2 \mu \mathrm{l}$ of PVP-40 (10\% concentration by weight), $0.3 \mu \mathrm{l}$ of $10 \mu \mathrm{M}$ primer GVGF1, $0.3 \mu \mathrm{l}$ of $10 \mu \mathrm{M}$ primer GVGR1, $1.0 \mu \mathrm{l}$ of DNA extract, and $6.4 \mu \mathrm{l}$ of Millipore water. A threshold cycle $(\mathrm{Ct})$ value of 30.0 was selected as the upper cutoff for a positive result on the condition that the melting point $(\mathrm{Tm})$ was within $\pm 2{ }^{\circ} \mathrm{C}$ compared with the positive control of the plate on which it was run.

Spatial analysis of virus infection patterns. Spatial analysis by distance indices. The program Spatial Analysis by Distance Indices (SADIE) was used to analyze patterns of GRBV infection (Perry 1995; Perry et al. 1999). An extension of the SADIE program was used for further analysis of association or dissociation of distributional patterns of infected vines within a site across years (Winder et al. 2001). Analysis using SADIE was not conducted at Milton-Freewater or in Jacksonville in 2014 because the incidence of infected vines was below 5\% (Pethybridge and Turechek 2003).

The SADIE program integrates spatial coordinates along with count or incidence data and creates random permutations of the data. By comparing the distance to regularity $(D)$ of actual versus simulated data, permutations produce a value against which the actual data are compared to provide a measure of significance of aggregation $\left(P_{a}\right.$; $\alpha<0.05)$, as well as outputs of the index of aggregation $\left(I_{a}\right)$ and degrees of clustering $\left(v_{i j}\right)$. When $I_{a}>1$ clustering of counts is aggregated, $I_{a}<1$ indicates regular arrangement of counts and $I_{a}=1$ indicates a random arrangement of counts (Madden et al. 2007). Degree of clustering is statistically significant when $v_{i}>1.5$, indicating a higher than average concentration of virus-infected vines, or when $v_{j}<-1.5$, indicating a lower than average concentration of virus-infected vines. As values of $v_{i j}$ increase or decrease above or below these values, the strength of the patch or gap, respectively, likewise increases (Perry et al. 1999).

To assess the possible association or dissociation of GRBV-infected vines between years, the infection status of sampled vines was compared between years. Between-year comparisons were made for the coupled years 2015 to 2016 in all sites that contained vines infected with GRBV, and additionally for the coupled years 2014 to 2015 and 2014 to 2016 for Yamhill and Talent. Within a given association analysis between two seasons, the parameter $X$ represented the measure of spatial association between the two cluster indices. The Dutilleul-corrected $N$ represented the effective sample size, accounting for autocorrelation within a vineyard but distinct from the actual $N$ used by the statistical program (Dutilleul et al. 1993). The significance of association was determined by interpretation of $P_{\mathrm{X}}$, where $P_{\mathrm{X}}<$ 0.025 indicated that the infection status of vines was significantly spatiotemporally associated, $P_{\mathrm{X}}>0.975$ indicated a significant spatiotemporal dissociation of infected vines, and intermediate values $0.025<$ $P_{\mathrm{X}}<0.975$ indicated a nonsignificant random association of incidence of infection across years.
During the study, diagnostic tests resulted in unexpected differential results for a small proportion of assayed vines (2.6\%). In these cases, a vine tested positive for GRBV in an earlier season but tested negative during a later season. Frozen material from these vines was retested at the conclusion of the study, resulting in similar findings. All vines testing negative for GRBV following a positive result from previous seasons were counted as GRBV positive in subsequent seasons for the purpose of spatial analysis.

Quadrat analysis. To make further inference on the in-vineyard spatial patterns of GRBV infection, binomial distribution (BD) and $\beta$-binomial distribution ( $\beta B D$ ) analyses were compared on quadrats within study sites as described by Madden et al. (2007). Analyzed sites were assessed for the cumulative infection of vines at the end of the three seasons $(2014,2015$, and 2016). Vineyard blocks with GRBV infection were divided into site-specific quadrats of relevant sizes. At Jacksonville, the vineyard block was divided into 50 quadrats measuring 8 vines $\times 4$ rows in size. Because every fourth vine and only evennumbered rows were surveyed at this site, four surveyed vines were analyzed at the quadrat scale. At Talent, 25 quadrats measuring 10 vines $\times 4$ rows were evaluated and contained eight surveyed vines per quadrat. At Yamhill, 25 quadrats measuring 14 vines $\times 4$ rows were evaluated. Because of the closer spacing of the rows, this site had 16 surveyed vines per quadrat. In limited instances, fewer surveyed vines were contained within a quadrat than is schematically listed.

$\mathrm{BD}$ and $\beta \mathrm{BD}$ analyses were conducted using the BBD program developed by Madden and Hughes (1994). BD is an appropriate analytical tool when infection is distributed randomly within a study block. However, in cases where the estimate of unbiased variance of distribution of infection is large, a clustered pattern is evident. In such cases of overdispersion, the $\beta \mathrm{BD}$ may have an explanative function. $\beta \mathrm{BD}$ analysis produces the intracluster correlation coefficient $\rho$ and an index of aggregation $\theta$. In quadrat analysis, positive values where $0<\rho<1$ indicate the tendency for plants within a quadrat to have the same infection status as other plants. As $\theta$ increases, $\rho$ approaches its asymptote $=1$ (Madden et al. 2007). The BBD program calculates the parameter log likelihood for both BD and $\beta B D$, providing a $\chi^{2}$ statistic against which to compare BD to $\beta B D$ (Madden and Hughes 1994). This is expressed as the likelihood ratio test probability that, when significant at $\alpha<0.05$, indicates a better fit of the $\beta B D$ model over the BD model.

\section{Results}

The year-by-year outcomes of GRBV detection using qPCR analysis from 2013 to 2016 are summarized in Table 1. Samples collected from 2013 to 2015 at the Milton-Freewater site did not reveal the presence of GRBV. At all other sites, GRBV was present and the cumulative incidence of infection increased annually (Fig. 1; Table 2).

Leaf material from Talent revealed that the cumulative proportion of vines infected by GRBV was $10.4 \%$ in $2014,19.0 \%$ in 2015 , and $21.5 \%$ in 2016 . Grapevines at Talent displayed significant patterns of overdispersion within the block, as represented by virus distribution

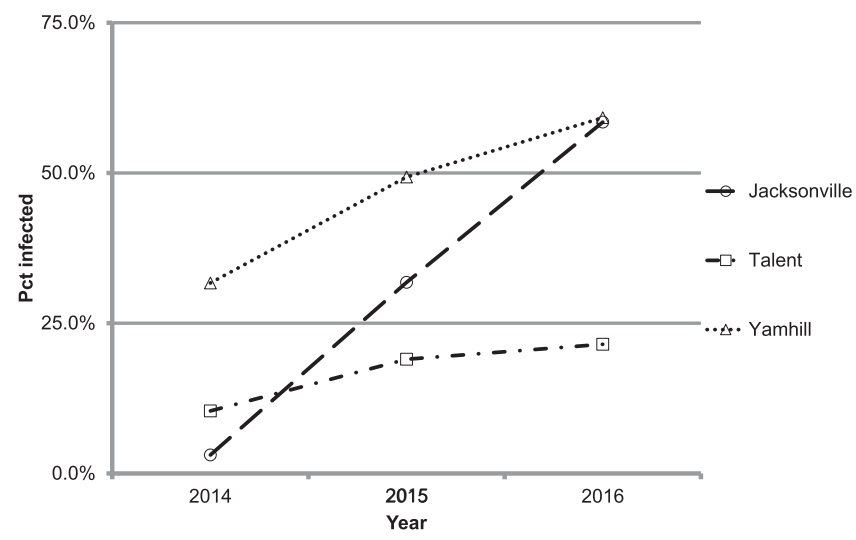

Fig. 1. Change in the incidence of cumulative infection by grapevine red blotch virus (GRBV) as determined by quantitative polymerase chain reaction on vines repeatedly assayed from 2013 to 2016 in three Oregon vineyard sites. Assays of vines from Milton-Freewater revealed no incidence of GRBV (data not shown). 
mapping over the course of the study (Fig. 2). Spatiotemporal analysis indicated a strong association of GRBV-infected vines at Talent across all years of the study (Table 3). Aggregation of infected vines, as indicated by increasing values of $\theta$, increased annually (Table 4).

Epidemiological studies began at Jacksonville in 2014. Of the material collected in $2014,3.1 \%$ of sampled vines tested positive for GRBV, compared with $31.8 \%$ of cumulatively positive vines in 2015 and $58.5 \%$ of cumulatively positive vines in 2016 (Fig. 1). SADIE was not possible in 2014 because of a low $(<5 \%)$ incidence of infection, and spatiotemporal association analysis could only be conducted between years 2015 and 2016. Plants infected with GRBV were spatially associated between these two seasons (Table 3). $\beta B D$ analysis showed that the $\beta B D$ model was a superior fit to the BD model in 2015 and in 2016 (Table 4). The spatiotemporal distribution of GRBV at Jacksonville is depicted in Figure 3.
Table 3. Spatial Analysis by Distance Indices (SADIE, Perry 1995) association analysis between vines infected with grapevine red blotch virus (GRBV) across years in three Oregon vineyards ${ }^{\mathrm{a}}$

\begin{tabular}{lccccc}
\hline Site & Year $\mathbf{1}$ & Year 2 & $\boldsymbol{N}$ & $\boldsymbol{\chi}^{\mathbf{2}}$ & $\boldsymbol{P}_{\boldsymbol{\chi}}$ \\
\hline Jacksonville & 2015 & 2016 & 189.8 & 0.576 & $<0.001$ \\
Talent & 2014 & 2015 & 168.6 & 0.687 & $<0.001$ \\
& 2014 & 2016 & 161.5 & 0.635 & $<0.001$ \\
& 2015 & 2016 & 141.0 & 0.925 & $<0.001$ \\
Yamhill & 2014 & 2015 & 348.5 & 0.668 & $<0.001$ \\
& 2014 & 2016 & 355.2 & 0.552 & $<0.001$ \\
& 2015 & 2016 & 319.3 & 0.819 & $<0.001$ \\
\hline
\end{tabular}

a $N$ is the Dutilleul-corrected sample size to account for autocorrelation. The cumulative incidence of GRBV is statistically associated when $P_{\chi}<0.025$, statistically dissociated when $P_{\chi}>0.975$, and random when $0.025<P_{\chi}<$ 0.975 .

Table 2. Cumulative incidence of grapevine red blotch virus (GRBV) in four Oregon vineyards from 2013 to 2016 , as determined using quantitative polymerase chain reaction $^{\mathrm{a}}$

\begin{tabular}{|c|c|c|c|c|c|c|c|c|}
\hline Site & Year & $N$ & $\%$ infected & $I_{a}$ & $\overline{V j}$ & $\overline{V i}$ & $D$ & $P_{a}$ \\
\hline \multirow[t]{2}{*}{ Milton-Freewater } & 2013 to 2014 & 395 & 0.0 & N/A & N/A & N/A & N/A & N/A \\
\hline & 2015 & 395 & 0.0 & N/A & N/A & N/A & N/A & N/A \\
\hline \multirow[t]{3}{*}{ Jacksonville } & 2014 & 194 & 3.1 & N/A & N/A & N/A & N/A & N/A \\
\hline & 2015 & 195 & 31.8 & 4.30 & -4.48 & 4.28 & 957.5 & $<0.001$ \\
\hline & 2016 & 195 & 58.5 & 1.17 & -1.21 & 1.17 & 276.1 & 0.189 \\
\hline \multirow[t]{3}{*}{ Talent } & 2014 & 193 & 10.4 & 1.99 & -1.95 & 2.01 & 195.9 & 0.002 \\
\hline & 2015 & 200 & 19.0 & 2.30 & -2.23 & 2.41 & 299.9 & $<0.001$ \\
\hline & 2016 & 200 & 21.5 & 2.17 & -2.11 & 2.24 & 298.8 & 0.001 \\
\hline \multirow[t]{3}{*}{ Yamhill } & 2013 to 2014 & 363 & 31.7 & 3.78 & -4.03 & 3.64 & $1,034.9$ & $<0.001$ \\
\hline & 2015 & 375 & 49.3 & 4.37 & -4.80 & 4.16 & $1,316.4$ & $<0.001$ \\
\hline & 2016 & 375 & 59.2 & 4.46 & -4.95 & 4.24 & $1,318.2$ & $<0.001$ \\
\hline
\end{tabular}

a The indices presented using the program Spatial Analysis by Distance Indices (SADIE; Perry 1995) are as follows: $I_{a}=$ index of aggregation, $\overline{V j}=$ mean index of gap strength, $\overline{V i}=$ mean index of patch strength, and $D=$ distance to regularity. Values are significant when the significance of aggregation $\left(P_{a}\right)$ is $<0.05$. Site-years in which infection was $<5 \%$ or $>95 \%$ were not analyzed using SADIE. N/A = not analyzed using SADIE.

\begin{tabular}{|c|c|c|c|c|c|c|c|c|c|c|c|c|c|c|c|c|c|c|c|c|}
\hline & \multicolumn{20}{|c|}{ Row } \\
\hline & 19 & 20 & 21 & 22 & 23 & 24 & 25 & 26 & 27 & 28 & 29 & 30 & 31 & 32 & 33 & 34 & 35 & 36 & 37 & 38 \\
\hline $48 / 49$ & 3 & 2 & 2 & 3 & 3 & 2 & 3 & 2 & 3 & 3 & 3 & 3 & 3 & 3 & 3 & 3 & 3 & 3 & 3 & 3 \\
\hline$\overline{43}$ & 3 & 3 & 3 & 3 & 3 & 3 & 3 & 3 & 3 & 3 & 3 & 3 & 3 & 3 & 3 & 3 & 3 & 3 & 3 & 3 \\
\hline $38 / 39$ & 3 & 3 & 3 & 2 & 3 & 3 & 3 & 3 & 2 & 3 & 3 & 3 & 3 & 3 & 3 & 3 & 2 & 3 & 3 & 3 \\
\hline$\overline{33}$ & 3 & 3 & 3 & $\overline{3}$ & 3 & 3 & 3 & 3 & 3 & 3 & 3 & 3 & 3 & 3 & 3 & 3 & 3 & 3 & 3 & 3 \\
\hline \multirow{2}{*}{ Vine } & 3 & 3 & 3 & 3 & 3 & 3 & 3 & 3 & 3 & 3 & 3 & 3 & 3 & 3 & 3 & 3 & 3 & 2 & 3 & 3 \\
\hline & 3 & 3 & 3 & 3 & 3 & 3 & 3 & 3 & 3 & 3 & 3 & 3 & 3 & 3 & 3 & 3 & 3 & 3 & 3 & 3 \\
\hline 18 & 3 & 3 & 3 & 3 & 3 & 3 & 2 & 3 & 3 & 3 & 3 & 3 & 3 & 3 & 3 & 3 & 3 & 3 & 2 & 3 \\
\hline 13 & 3 & 3 & 3 & 3 & 3 & 3 & 3 & 3 & 3 & 3 & 3 & 3 & 3 & 3 & 3 & 3 & 3 & 3 & 3 & 3 \\
\hline 8 & 3 & 3 & 3 & 3 & 3 & 3 & 3 & 2 & 3 & 3 & 3 & 3 & 3 & 3 & 3 & 3 & 3 & 3 & 3 & 3 \\
\hline 3 & 3 & 3 & 3 & 3 & 3 & 3 & 3 & 3 & 3 & 3 & 3 & 3 & 3 & 3 & 3 & 3 & 3 & 3 & 3 & 3 \\
\hline
\end{tabular}

\begin{tabular}{|c|r|}
\hline Color Code & Year First Positive \\
\hline$x$ & positive then negative \\
\hline$x$ & 2014 \\
\hline$x$ & 2015 \\
\hline$x$ & 2016 \\
\hline$x$ & never \\
\hline
\end{tabular}

Fig. 2. Distribution of grapevine red blotch virus (GRBV) at Talent (southern Oregon). Cells represent individual vines that were repeatedly assayed using quantitative polymerase chain reaction from 2014 to 2016. The legend provides a color code indicating the first year in which a vine first tested positive for GRBV. Numbers within cells indicate how many times a vine was tested. Underlined numbers indicate the location of vine samples that deviated from a predetermined grid pattern. Figure not drawn to scale. 
At Yamhill in 2013 and 2014, two distinct sets of vines were examined within the same vineyard rows but were combined for analytical purposes and expressed as combined data in year 2014. These assayed vines had a combined incidence of $31.1 \%$ GRBV infection.
However, the GRBV incidence of infection had increased in the same vines to $49.3 \%$ by 2015 . Additional vines that tested positive in 2016 but negative in previous seasons brought the overall proportion of GRBV-infected vines at Yamhill to 59.2\% (Fig. 1). Locations of

Table 4. Comparison of binomial distribution $(\mathrm{BD})$ and $\beta$-binomial distribution $(\beta \mathrm{BD})$ analyses ${ }^{\mathrm{a}}$

\begin{tabular}{|c|c|c|c|c|c|c|c|c|c|}
\hline \multirow[b]{2}{*}{ Site } & \multirow[b]{2}{*}{ Year } & \multirow[b]{2}{*}{ Quadrat size (vines) } & \multicolumn{2}{|c|}{ BD analysis } & \multicolumn{4}{|c|}{$\beta B D$ analysis } & \multirow[b]{2}{*}{ LRTP } \\
\hline & & & $p_{B D}$ & Log likelihood & $p_{\beta B D}$ & $\boldsymbol{\theta}$ & $\rho$ & Log likelihood & \\
\hline \multirow[t]{3}{*}{ Jacksonville } & 2014 & $8 \times 4$ & 0.031 & 38.9 & 0.031 & 0.102 & 0.093 & 37.6 & 0.107 \\
\hline & 2015 & $8 \times 4$ & 0.313 & 161.1 & 0.316 & 0.395 & 0.283 & 144.8 & $<0.001$ \\
\hline & 2016 & $8 \times 4$ & 0.585 & 152.7 & 0.585 & 0.135 & 0.119 & 149.1 & 0.007 \\
\hline \multirow[t]{3}{*}{ Talent } & 2014 & $10 \times 4$ & 0.104 & 65.5 & 0.105 & 0.089 & 0.082 & 61.9 & 0.007 \\
\hline & 2015 & $10 \times 4$ & 0.170 & 87.8 & 0.170 & 0.171 & 0.146 & 79.4 & $<0.001$ \\
\hline & 2016 & $10 \times 4$ & 0.215 & 102.1 & 0.215 & 0.232 & 0.188 & 87.9 & $<0.001$ \\
\hline \multirow[t]{3}{*}{ Yamhill } & 2014 & $14 \times 4$ & 0.307 & 188.3 & 0.301 & 0.319 & 0.242 & 126.6 & $<0.001$ \\
\hline & 2015 & $14 \times 4$ & 0.459 & 286.3 & 0.470 & 0.714 & 0.417 & 136.3 & $<0.001$ \\
\hline & 2016 & $14 \times 4$ & 0.592 & 247.1 & 0.600 & 0.519 & 0.342 & 135.5 & $<0.001$ \\
\hline
\end{tabular}

${ }^{a} p B D$ and $p \beta B D$ indicate the estimated likelihood that a plant will be infected with grapevine red blotch virus using BD and $\beta B D$ analysis, respectively. In $\beta B D$ analysis, $\theta$ is the index of aggregation and $\rho$ is a measure of the departure from the binomial distribution. The likelihood ratio test probability (LRTP) is a comparison of log likelihood metrics between $\mathrm{BD}$ and $\beta \mathrm{BD}$ analyses. $\beta \mathrm{BD}$ is the preferred test when LRTP $<0.05$.

Row

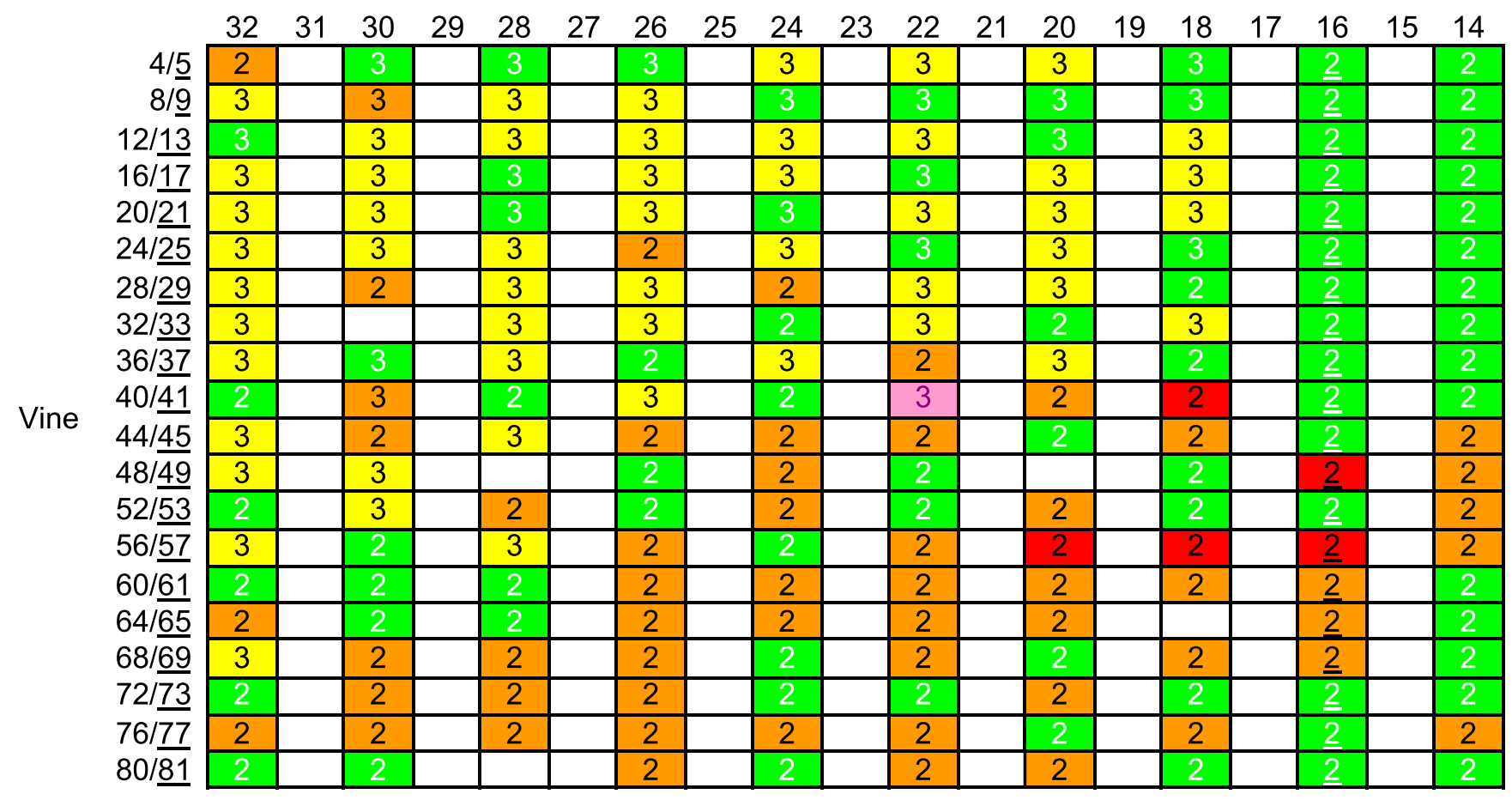

\begin{tabular}{|c|r|}
\hline Color Code & Year First Positive \\
\hline$x$ & positive then negative \\
\hline$x$ & 2014 \\
\hline$x$ & 2015 \\
\hline$x$ & 2016 \\
\hline$x$ & never \\
\hline
\end{tabular}

Fig. 3. Distribution of grapevine red blotch virus (GRBV) at Jacksonville (southern Oregon). Cells represent individual vines that were repeatedly assayed using quantitative polymerase chain reaction from 2014 to 2016. The legend provides a color code indicating the first year in which a vine first tested positive for GRBV. Numbers within cells indicate how many times a vine was tested. Underlined numbers indicate the location of vine samples that deviated from a predetermined grid pattern. Empty cells indicate vines that were sampled less than two times during the study period. Figure not drawn to scale. 
GRBV-infected and uninfected vines were associated across all years (Table 3). Areas of aggregation, as represented by the $\beta B D$ parameter $\theta$, increased and were spatially associated across all years (see Table 4). The spatiotemporal distribution of GRBV at the conclusion of the study is presented for Yamhill in Figure 4.

Over the course of the study, the average Tm of positive controls generated from the 7500 Fast System was $76.79^{\circ} \mathrm{C}$; for the QuantStudio 6 Flex, $\backslash$ the average $\mathrm{Tm}$ of positive controls was $81.81^{\circ} \mathrm{C}$. The median $\mathrm{Tm}$ was $59.85^{\circ} \mathrm{C}$ with no measurable $\mathrm{Ct}$ value for $94.2 \%$ of all samples that were scored as GRBV negative (data not shown).

\section{Discussion}

The current study is the first to report spatial patterns and spread of GRBV in Oregon vineyards. Researchers have verified the spread of the virus in California from highly aggregated sections of a vineyard originating at the edge and extending toward the center of the block (Cieniewicz et al. 2017). Our assessment of the infection status of tested vines showed a significant trend of increase of GRBV incidence in three of the four Oregon vineyard study sites. The annual increase of virus incidence was rapid, with observed doubling to 10-fold increases recorded in sites from 2014 to 2016. In a survey conducted in 2016 by the Oregon Department of Agriculture, GRBV was found in all wine grape production regions of Oregon, including in the Columbia Basin of eastern Oregon (D. Poudyal, personal communication). Thus, the findings of the current study do not represent a complete picture of
GRBV in Oregon, but rather confirm that spread of GRBV is taking place in at least two geographical regions of Oregon.

We analyzed the association or dissociation of spatial patterns of GRBV-infected vines between years. In all vineyards and between years, the spatial pattern of virus incidence was associated with the previous time period (see Table 3 ). The rapid increase of GRBV recorded in the vineyard in Jacksonville is unique, as demonstrated by qPCR assays over the 3 years of the study. In 2014, the incidence of infected vines was $3.1 \%$ and spatial analysis by SADIE was not possible. By 2016, most vines were infected with GRBV, and uninfected vines were randomly distributed throughout the block. These observations explain why there was a statistically clumped distribution of GRBV-positive vines only in 2015. The overall proportion of infected vines in Jacksonville is likely a conservative figure because many vines that tested negative for GRBV in 2015 were removed by the grower before the 2016 field collections. Most of the previously surveyed vines at Jacksonville that remained in the study block in 2016 tested positive for GRBV (see Table 1).

The observed in-field spatial pattern of GRBV infection supports spread by an insect vector. Evidence exists for vector transmission of both GLRaVs (Almeida et al. 2013) and GRBV (Bahder et al. 2016; Cieniewicz et al. 2018). Spread of GLRaV occurs slowly from established foci of infection. Female mealybug and scale insect vectors of GLRaVs are wingless and migrate slowly along the vine during the

\begin{tabular}{|c|c|c|c|c|c|c|c|c|c|c|c|c|c|c|c|c|c|c|c|}
\hline & 63 & 62 & 61 & 60 & 59 & 58 & 57 & 56 & 55 & $\begin{array}{l}\text { Row } \\
54\end{array}$ & 53 & 52 & 51 & 50 & 49 & 48 & 47 & 46 & 45 \\
\hline 28 & 3 & 3 & 3 & 3 & 3 & 3 & 3 & 3 & 3 & 3 & 3 & 3 & 2 & 3 & 3 & 3 & 3 & 3 & 3 \\
\hline 31 & 2 & 3 & 3 & 3 & 2 & 2 & 2 & 3 & 3 & 3 & 2 & 3 & 2 & 3 & 3 & 3 & 3 & 3 & 3 \\
\hline 35 & 3 & 3 & 3 & 3 & 3 & 3 & 3 & 3 & 2 & 3 & 3 & 3 & 2 & 3 & 3 & 3 & 3 & 3 & 3 \\
\hline 38 & 2 & 3 & 2 & 3 & 2 & 3 & 2 & 3 & 3 & 2 & 3 & 3 & 2 & 3 & 3 & 2 & 3 & 3 & 3 \\
\hline 42 & 3 & 3 & 3 & 3 & 3 & 3 & 2 & 2 & 2 & 2 & 2 & 2 & 3 & 3 & 3 & 3 & 3 & 3 & 3 \\
\hline 45 & 2 & 2 & 2 & 2 & 2 & 3 & 2 & 3 & 3 & 2 & 3 & 2 & 2 & 3 & 3 & 3 & 3 & 3 & 3 \\
\hline 49 & 2 & 3 & 3 & 3 & 3 & 2 & 3 & 3 & 2 & 3 & 2 & 3 & 3 & 3 & 3 & 3 & 3 & 3 & 3 \\
\hline 52 & 3 & 2 & 2 & 2 & 2 & 3 & & 3 & 2 & 2 & 2 & 2 & 3 & 2 & 3 & 2 & 2 & 2 & 3 \\
\hline 56 & 2 & 2 & 2 & 2 & 2 & 2 & 2 & 2 & 2 & 2 & 2 & 2 & 2 & 3 & 2 & 2 & 3 & 2 & 3 \\
\hline 59 & 2 & 2 & 3 & 2 & 2 & 2 & 3 & 2 & 2 & 2 & 2 & 2 & 2 & 3 & 3 & 2 & 2 & 2 & 3 \\
\hline 63 & 2 & 2 & 2 & 2 & 2 & 2 & 2 & 2 & 2 & 2 & 2 & 3 & 3 & 2 & 2 & 3 & 3 & 3 & \\
\hline 66 & 2 & 2 & 2 & 2 & 2 & 2 & 2 & 2 & 2 & 3 & 2 & 2 & 3 & 2 & 2 & 3 & 2 & & \\
\hline 70 & 2 & 2 & 2 & 2 & 2 & 2 & 2 & 2 & 2 & 2 & 2 & 2 & 2 & 2 & 3 & 3 & 3 & 3 & \\
\hline 73 & 2 & 2 & 2 & 2 & 2 & 2 & 2 & 2 & 2 & 2 & 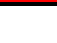 & 2 & 2 & 2 & 2 & 3 & 2 & 3 & \\
\hline 77 & 2 & 2 & 2 & 2 & 2 & 2 & 2 & 2 & 2 & 3 & 2 & 2 & 2 & 3 & 3 & 3 & 2 & 3 & \\
\hline 80 & 2 & 2 & 2 & 2 & 2 & 2 & 2 & 2 & 2 & 2 & 2 & 3 & 2 & 3 & 2 & 3 & 3 & 2 & \\
\hline 84 & 2 & 2 & 2 & 2 & 2 & 2 & 2 & 2 & 2 & 2 & 3 & 2 & 3 & 2 & 3 & 3 & 3 & 3 & \\
\hline 87 & 2 & 2 & 2 & 2 & 2 & 2 & 2 & 2 & 2 & 3 & 2 & 3 & 2 & 3 & 3 & 3 & 3 & 2 & \\
\hline$\underline{90 / 91}$ & 2 & 2 & 2 & 3 & 2 & 2 & 3 & 3 & 3 & 3 & 3 & 2 & 3 & 3 & $\underline{3}$ & $\underline{3}$ & $\underline{3}$ & 3 & \\
\hline 94 & 2 & 2 & 3 & 2 & 2 & 2 & 2 & & 3 & 3 & 2 & 3 & 3 & 3 & 3 & 3 & 3 & 3 & \\
\hline
\end{tabular}

\begin{tabular}{|c|r|}
\hline Color Code & Year First Positive \\
\hline$x$ & positive then negative \\
\hline$x$ & $2013-2014$ \\
\hline$x$ & 2015 \\
\hline$x$ & 2016 \\
\hline$x$ & never \\
\hline
\end{tabular}

Fig. 4. Distribution of grapevine red blotch virus (GRBV) at Yamhill (Willamette Valley). Cells represent individual vines that were repeatedly assayed using quantitative polymerase chain reaction from 2013 to 2016 . The legend provides a color code indicating the first year in which a vine first tested positive for GRBV. Numbers within cells indicate how many times a vine was tested. Underlined numbers indicate the location of vine samples that deviated from a predetermined grid pattern. Empty cells indicate vines that were sampled less than two times during the study period. Figure not drawn to scale. 
growing season (Bahder et al. 2013), while winged adult males do not feed (Borges da Silva et al. 2009). The historical appearance of TPCTV in Florida tomato fields, transmitted by the membracid M. malleifera, rarely spread more than 30 to $60 \mathrm{~m}$ from the field edge, with minimal secondary spread, likely attributable to low in-field movement of an insect vector (Simons 1962). Transmission of TPCTV was further associated with annual weeds within the field and along a bordering drainage ditch, with decreasing rates of infection as distance from the field margin increased (Simons and Coe 1958). The confirmed treehopper vector of GRBV is alate and has the potential to rapidly move throughout the vineyard as an adult. Thus, although GLRaV spread occurs in close proximity to previously infected vines (Almeida et al. 2013), new infections of GRBV were sometimes recorded in areas of the vineyard study blocks that had not been previously afflicted with virus. The rapid spread of GRBV as observed in Jacksonville has not been recorded previously but strongly indicates the presence of an insect vector.

Within the subfamily Smiliinae, the membracid tribe Ceresini contains closely related genera Spissistilus and Tortistilus (Cryan et al. 2000). Populations of $S$. festinus were observed in a California vineyard where the spatiotemporal spread of GRBV was examined (Cieniewicz et al. 2017). This species, together with other species in the genus Tortistilus, was found in the Jacksonville vineyard that was part of the current study (R. J. Hilton, unpublished data). In contrast, only Tortistilus was observed at the Talent and Yamhill study sites. Given the observed spread of GRBV in multiple locations in Oregon, including in locations that do not apparently have the confirmed presence of the vector S. festinus, it is plausible that multiple species of membracids may transmit GRBV. It is noteworthy that vines in vineyards where GRBV spread was documented in this study exhibited feeding damage consistent with feeding by resident populations of treehoppers (Walton, unpublished data). It is possible that these insect species may have contributed to the spread of the virus in the study vineyards. Currently, however, there is no conclusive evidence to confirm that Tortistilus insects are vectors of GRBV. Given the observed spread reported in the current study, the next logical step is to conduct controlled transmission bioassays using suspected vector species from study sites (Bahder et al. 2016). Detailed spatiotemporal studies on the biology and ecology of potential insect vectors will help determine population dynamics and target biological weaknesses of vector populations for management.

It is challenging to effectively manage GRBV without a strong understanding of the epidemiology of the virus. It is clear that RBD has a significant economic impact on vineyards (Ricketts et al. 2017). It is important that growers implement a focused monitoring effort to identify and remove infected vines in such areas as a first step to minimize the spread of the virus (Cieniewicz et al. 2017). This work provides advancement to the understanding of the epidemiology of RBD. Multiple aspects of the epidemiology of RBD are still poorly understood and knowledge gaps remain. Some of these gaps include a better understanding of the underlying reason for the significant differences in the rate of spread, as was recorded in this study, identification of possible additional insect vectors, and advances in transmission biology. Continued focus on these and other gaps will aid to more optimally manage the spread of RBD.

\section{Acknowledgments}

We thank David Gent for statistical help. We also thank Andy Swan, Cindy Preto, Meredith Shaffer, Trent Lawler, Kei-Lin Ooi, Kai Blaisdell, Shannon Davis, Lora Stamper, Gabriella Boyer, Alexander Soohoo-Hui, and Mukesh Bhattarai for technical assistance.

\section{Literature Cited}

Al Rwahnih, M., Alabi, O. J., Westrick, N. M., and Golino, D. 2018. Prunus geminivirus A: A novel Grablovirus infecting Prunus spp. Plant Dis. 102: 1246-1253.

Al Rwahnih, M., Ashita, D., Anderson, M. M., Rowhani, A., Uyemoto, J. K., and Sudarshana, M. R. 2013. Association of a DNA virus with grapevines affected by red blotch disease in California. Phytopathology 103:1069-1076.

Almeida, R. P. P., Daane, K. M., Bell, V. A., Blaisdell, G. A., Cooper, M. L., Herrbach, E., and Pietersen, G. 2013. Ecology and management of grapevine leafroll disease. Front. Microbiol. 4:94.
Bahder, B. W., Poojari, S., Alabi, O. J., Naidu, R. A., and Walsh, D. B. 2013 Pseudococcus maritimus (Hemiptera: Pseudococcidae) and Parthenolecanium corni (Hemiptera: Coccidae) are capable of transmitting grapevine leafrollassociated virus 3 between Vitis x labruscana and Vitis vinifera. Environ. Entomol. 42:1292-1298.

Bahder, B. W., Zalom, F. G., Jayanth, M., and Sudarshana, M. R. 2016. Phylogeny of geminivirus coat protein sequences and digital PCR aid in identifying Spissistilus festinus as a vector of Grapevine red blotch-associated virus. Phytopathology 106:1223-1230.

Blanco-Ulate, B., Hopfer, H., Figueroa-Balderas, R., Ye, Z., Rivero, R. M., Albacete, A., Pérez-Alfocea, F., Koyama, R., Anderson, M. M., Smith, R. J., Ebeler, S. E., and Cantu, D. 2017. Red blotch disease alters grape berry development and metabolism by interfering with the transcriptional and hormonal regulation of ripening. J. Exp. Bot. 68:1225-1238.

Borges da Silva, E., Mouco, R. A., Antunes, R., Mendel, Z., and Franco, J. C. 2009. Mate location and sexual maturity of adult male mealybugs: Narrow window of opportunity in a short lifetime. IOBC WPRS Bull. 41:3-9.

Cieniewicz, E. J., Pethybridge, S. J., Gorny, A., Madden, L. V., McLane, H., Perry, K. L., and Fuchs, M. 2017. Spatiotemporal spread of grapevine red blotchassociated virus in a California vineyard. Virus Res. 241:156-162.

Cieniewicz, E. J., Pethybridge, S. J., Loeb, G., Perry, K., and Fuchs, M. 2018. Insights into the ecology of grapevine red blotch virus in a diseased vineyard. Phytopathology 108:94-102.

Cryan, J. R., Wiegmann, B. M., Deitz, L. L., and Dietrich, C. H. 2000. Phylogeny of the treehoppers (Insecta: Hemiptera: Membracidae): Evidence from two nuclear genes. Mol. Phylogenet. Evol. 17:317-334.

Dutilleul, P., Clifford, P., Richardson, S., and Hemon, D. 1993. Modifying the $t$ test for assessing the correlation between two spatial processes. Biometrics 49:305-314.

Goeden, R. D., and Ricken, D. W. 1986. Phytophagous insect faunas of the two most common native Cirsium Thistles, C. californicum and C. proteanum, in Southern California. Ann. Entomol. Soc. Am. 79:953-962.

Jones, G. V., McLain, M., and Hendricks, S. 2003. Winegrowing regions. Pages 51-69 in: Oregon Viticulture. E. W. Hellman, ed. Oregon State University Press, Corvallis.

Kopp, D. D., and Yonke, T. R. 1979. A taxonomic review of the tribe Ceresini (Homoptera: Membracidae). Miscell. Publ. Entomol. Soc. Am. 11:1-97.

Krenz, B., Thompson, J. R., Fuchs, M., and Perry, K. L. 2012. Complete genome sequence of a new circular DNA virus from grapevine. J. Virol. $86: 7715$.

Madden, L. V., and Hughes, G. 1994. BBD-computer software for fitting the beta-binomial distribution to disease incidence data. Plant Dis. 78:536-540.

Madden, L. V., Hughes, G., and van den Bosch, F. 2007. Spatial aspects of epidemics-III: Patterns of plant disease. Pages 235-278 in: The Study of Plant Disease Epidemics. L. V. Madden, G. Hughes, and F. van den Bosch, eds. American Phytopathological Society, St. Paul, MN.

Maliogka, V. I., Martelli, G. P., Fuchs, M., and Katis, N. I. 2015. Control of viruses infecting grapevine. Pages 175-227 in: Advances in Virus Research. Loebenstein, G., and Katis, N. I., eds. Vol. 91. Academic Press, Burlington, MA.

Martelli, G. P. 2014. Grapevine-infecting viruses. J. Plant Pathol. 96:7-8.

Naidu, R. P., Maree, H. J., and Burger, J. T. 2015. Grapevine leafroll disease and associated viruses: A unique pathosystem. Annu. Rev. Phytopathol. 53: 613-634.

Osman, F., Olineka, T., Hodzic, E., Golino, D., and Rowhani, A. 2012. Comparative procedures for sample processing and quantitative PCR detection of grapevine viruses. J. Virol. Methods 179:303-310.

Perry, J. N. 1995. Spatial analysis by distance indices. J. Anim. Ecol. 64:303-314.

Perry, J. N., Winder, L., Holland, J. M., and Alston, R. D. 1999. Red-blue plots for detecting clusters in count data. Ecol. Lett. 2:106-113.

Perry, K. L., McLane, H., Thompson, J. R., and Fuchs, M. 2018. A novel grablovirus from non-cultivated grapevine (Vitis sp.) in North America. Arch. Virol. 163:259-262.

Pethybridge, S. J., and Turechek, W. W. 2003. Analysis of the association among three viruses infecting hop in Australia. Plant Pathol. 52:158-167.

Poojari, S., Alabi, O. J., Fofanov, V. Y., and Naidu, R. A. 2013. A leafhoppertransmissible DNA virus with novel evolutionary lineage in the family Geminiviridae implicated in grapevine redleaf disease by next-generation sequencing (correction published in PLoS One. 2016;11:e0147510). PLoS One 8:e64194.

Ricketts, K. D., Gómez, M. I., Fuchs, M. F., Martinson, T. E., Smith, R. J., Cooper, M. L., Moyer, M. M., and Wise, A. 2017. Mitigating the economic impact of grapevine red blotch: Optimizing disease management strategies in U.S. vineyards. Am. J. Enol. Vitic. 68:127-135.

Seguin, J., Rajeswaran, R., Malpica-López, N., Martin, R. R., Kasschau, K., Dolja, V. V., Otten, P., Farinelli, L., and Pooggin, M. M. 2014. De novo reconstruc tion of consensus master genomes of plant RNA and DNA viruses from siRNAs. PLoS One 9:e88513.

Setiono, F. J., Chatterjee, D., Fuchs, M., Perry, K. L., and Thompson, J. R. 2018 The distribution and detection of Grapevine red blotch virus in its host depend on time of sampling and tissue type. Plant Dis. 102:2187-2193.

Simons, J. N. 1962. The pseudo-curly top disease in South Florida. J. Econ Entomol. 55:358-363. 
Simons, J. N., and Coe, D. M. 1958. Transmission of pseudo-curly top virus in Florida by a treehopper. Virology 6:43-48.

Sudarshana, M. R., Perry, K. L., and Fuchs, M. F. 2015. Grapevine red blotchassociated virus, an emerging threat to the grapevine industry. Phytopatho logy 105:1026-1032.

Swiecki, T. J., and Bernhardt, E. A. 2006. A Field Guide to Insects and Diseases of California Oaks. General Technical Report PSW-GTR-197. Pacific Southwest Research Station, Forest Service, U.S. Department of Agriculture, Albany, CA. doi:10.2737/PSW-GTR-197

Valenti, M. A., Ferrell, G. T., and Berryman, A. A. 1997. Insects and RelatedArthropods Associated with Greenleaf Manzanita in Montane Chaparral Communities of Northeastern California. General Technical Report PSW-GTR-167. Pacific Southwest Research Station, Forest Service, U.S. Department of Agriculture, Albany, CA:
Varsani, A., Roumagnac, P., Fuchs, M., Navas-Castillo, J., Moriones, E., Idris, A., Broddon, R. W., Rivera-Bustamante, R., Murilo Zerbini, F., and Martin, D. P. 2017. Capulavirus and Grablovirus: Two new genera in the family Geminiviridae. Arch. Virol. 162:1819-1831.

Walton, V. M., Dalton, D. T., Daane, K. M., Kaiser, C., and Hilton, R. J. 2013. Seasona phenology of Pseudococcus maritimus (Hemiptera: Pseudococcidae) and pheromone-baited trap survey of four important mealybug species in three wine grape growing regions of Oregon. Ann. Entomol. Soc. Am. 106:471-478.

Winder, L., Alexander, C. J., Holland, J. M., Woolley, C., and Perry, J. N. 2001. Modelling the dynamic spatio-temporal response of predators to transient prey patches in the field. Ecol. Lett. 4:568-576.

Yepes, L. M., Cieniewicz, E., Krenz, B., McLane, H., Thompson, J. R., Perry, K. L., and Fuchs, M. 2018. Causative role of grapevine red blotch virus in red blotch disease. Phytopathology 108:902-909. 